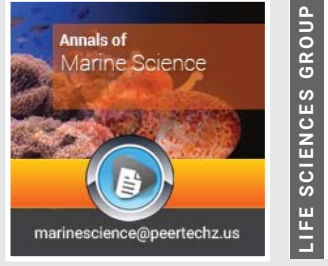

\title{
Stomach and gut content
} of Long Neck Croacker-

\section{Pseudotolithus typus}

\section{(Bleeker,1863) from Lagos}

Received: 01 March, 2021

Accepted: 30 March, 2021

Published: 31 March, 2021

*Corresponding author: Awotunde Mathew Olatunji, Aquaculture and Fisheries Management, University of Ibadan, Nigeria, Tel: +2348130908051; E-mail: olatunji.mat@gmail.com

Keywords: Lagos lagoon; Pseudotolithus typhus; Shrimps; Gut content; Stomach

https://www.peertechzpublications.com

\section{Check for updates}

\section{Lagoon, Nigera}

\section{Awotunde Mathew Olatunji*}

Aquaculture and Fisheries Management, University of Ibadan, Nigeria

\begin{abstract}
Pseudotolithus typus has been considered to hold great promise for fish farming in Africa, the fish having a wide geographical spread, a high growth rate, resistance to handling stress and well appreciated in a wide number of African countries. Studying its feeding habit, which is an important aspect of its biology, is a crucial knowledge needed for its mass cultivation by fish farmers and also its implication for its management in the wild. The main objective of the study was to investigate the food items and feeding activities of Pseudotolithus typus in the Lagos lagoon, Nigeria.

A total of 93 specimens were collected and transported in ice-packed container to the wet laboratory of the Department of Biological Oceanography, Nigerian Institute for Oceanography and Marine Research (NIOMR) for further examination. These specimens were usually collected during early hour of the morning. Specimens were weighed with Camry model EK5350 of $5 \mathrm{~kg}$ capacity to the nearest $0.10 \mathrm{~g}$ after blotting dry with filter paper Specimens were dissected and the gut were carefully removed with the aid of a forceps after dissection. Stomach and gut contents were examined and the individual food organisms sorted and counting the number of each food item present in the gut and stomach of the species and summing up these numbers to obtain the grand number of all food items in its guts. The number of non-empty guts divided by total number of guts examined, multiply by hundred was used to determine the guts repletion index. Index of fullness was measured as the ratio of food weight to body weight as an index of fullness. The sampling methods were season stratified.Data were subjected to one way analysis of variance (ANOVA) and significant differences accepted at $\mathrm{P}<0.05$ using statistical package (SPSS version 14).
\end{abstract}

The diet of Pseudotolithus typus was also analyzed. Frequency of occurrence, numerical abundance and Gut repletion index, stomach fullness were computed. The major dietary components of the species were shrimps. The food composition of $P$. typus shows seasonal variation with Bivalves conspicuously absent during the dry season. The frequency of occurrence of items in order of abundance revealed crustaceans (Peaneus notialis, Parapenaeopsis longirostrics and unidientified digested shrimps) followed undigested partly digested food items and less common items.

The diet composition of the Pseudotolithus typhus indicates they are specialised feeders depending on similar food sources with minimum number of dietary prey items. Shrimps and to some extent juvenile fishes constitute the important preys of Pseudotolithus typhus. Therefore the revolution of the abundance of food items must be assessed for their sustainable production and the extent of pollution in Lagos lagoon should be assessed due to the absence of bivalves(during the dry season) which are bio-indictors of pollutant to know what management strategies and control measures are to be taken.

\section{Introduction}

Feeding ecology is an important aspect of the life-history strategy of a species to understand the functional role of the fish within their ecosystems [1]. One of the most economically important and dominant species in the Nigerian coastal waters is Pseudotolithus typus.This species occurs in the estuaries and saline creek systems. Pseudotolithus typus is generally classified as omnivore or predator feeding mainly on aquatic insects, fish and plant debris. Pseudotolithus typus utilize various kinds of food resources available in their habitat [2].

The food and feeding habit of fish assemblage deals with their ability to have good nutritive foods which could improve 
their growth within their environment. Therefore, the dietary analysis of Pseudotolithus typus in their natural habitat enhances the understanding of their growth, abundance, productivity and distribution and seasonal fluxes in the type and magnitude of food available as well as the season it occurs. This study was designed to have the broad knowledge of the different species of prey in order to understand the quantitative connection between fish and their food organisms. Furthermore, this study adopts an ecosystem approach by quantifying the food organisms based on seasonal variation. This study presents more information on the gut and stomach content of Pseudotolithus typus in Lagos Lagoon. Previous reports on the Croakers in Nigeria include [3,4] and [5,6], also worked on Food habits of two species of Pseudotolithus (Sciaenidae) off Benin (West Africa) nearshore waters and implications for management and [7] also worked on Biometric characteristics, Food and feeding Habit and Sex Dimorphism of the Long Neck Croacker( Pseudotolithus typus ) from Lagos lagoon.

\section{Materials and methods}

\section{Study area}

Lagos State lies between longitude $3^{\circ} 21^{\prime \prime} 24^{\prime \prime E}$ and latitude $6^{\circ} 35^{\prime \prime} 8$ "N. It is located at the South-Western of Nigeria .Lagos State consists of twenty local governments. Ikeja currently serves as an administrative seat of the State and of a local government . The study area is Makoko, located in Lagos Mainland Local Government Area of Lagos State. Makoko is one of the many water and shoreline settlements in Lagos State. Makoko is a shanty settlement located in the centre of Lagos city, along the banks of the Lagos lagoon. Makoko lies within the south-eastern part of Lagos metropolis. It is bounded on the North by Iwaya and University of Lagos; at the West, by Ebute-Meta; South, by the Third Mainland Bridge; and East by the Lagos lagoon [8].

\section{Fish samples collection}

Samples of Pseudotolithus typus were randomly obtained from September 2018 to Febuary, 2019 from fishermen catches at Makoko landing point. The fish collection was done monthly for six consecutive months. A total of 93 specimens were collected and transported in ice-packed box to the wet laboratory of the Department of Biological Oceanography, Nigerian Institute for Oceanography and Marine Research (NIOMR) for further examination. These specimens were usually collected during early hour of morning.The sampling methods were season stratified. Seasonal stratification covered wet (September - November) and dry (December - February) seasons.

\section{Laboratory procedure}

The nomenclature of the fish samples taken to the laboratory for this study conformed to [9]. The fish specimens were treated individually to determine their biometric data. In the Laboratory, after blotting dry with filter paper Specimens were dissected and the gut were carefully removed with the aid of a forceps after dissection. The Stomach and the of dissected specimens were slit open and the contents displayed in Petri dishes with a small drops of distilled water added to agitate them and examined under a stereo light microscope(magnification up to $100 \times$ ) to identify the food items using appropriate taxonomic guide (FAO Marine Fish identification guide). Information on Total Length, Standard length, Weight and identified food items were recorded into a data sheet for data analysis.

\section{Food composition determination}

Two methods were used to assess the food composition of the fish. These methods included frequency of occurrence and numerical method [10].

\section{Frequency of occurrence}

Stomach contents were examined and the individual food organisms sorted and identified. The number of stomachs in which each item occurs were recorded and expressed as a percentage of the total number of stomachs examined.

\section{Frequency of Occurrence $=\mathrm{Ji} \div \mathrm{P}$}

Where, is number of fish containing prey $\mathrm{i}$ and $\mathrm{P}$ is the number of fish with food in their stomach. iJ

This method demonstrates what organisms are being fed upon, but it gives no information on quantities or numbers and does not take in to consideration the accumulation of food organisms resistant to digestion [11].

\section{Numerical method}

This involved counting the number of each food item present in the stomach of the species and summing up these numbers to obtain the grand number of all food items in its guts [12]. The number of each food was expressed as a percentage of the grand total number of food items. Usually expressed as:

$$
\text { Percentage number of food }=\frac{\text { Total number of a particular food item }}{\text { Total number of all food items }} \times 100
$$

This method expresses the numerical importance of different food items, and gives relative importance of each food item.

\section{Index of fullness}

This is measured as the ratio of food weight to body weight as an index of fullness. This index can be applied to the food in the stomach, or to that in the whole digestive tract. It is usually expressed as parts per 10,000 ( or parts per decimals).

Gut contents were analyzed quantitatively. The various food items are identified. The food content found in the stomach was divided into three groups.

1. Full: Stomach was full with food

2. $1 / 2$ Full: Stomach was $1 / 2$ full

3. Empty: Stomach without food 


\section{Guts Repletion Index (GRI)}

Guts repletion index is number of non-empty guts divided by total number of guts examined, multiply by 100 .

Represented as:

$$
\text { GRI }=\frac{\text { Number of non }- \text { empty guts }}{\text { Total number of guts examined }} \times 100
$$

\section{Statistical analysis}

Data obtained from the study were subjected to descriptive statistics (mean and standard deviation) and presented in graphs, pie chart and bar chart. Data were subjected to one way analysis of variance (ANOVA) and significant differences accepted at $\mathrm{P}<0.05$ using statistical package (SPSS version 14). Relationship between variables (Length and Weight) was analysed using regression.

\section{Results}

\section{Stomach fullness}

Figure 1-3 shows the degree of stomach fullness of Pseudotolithus typus samples during the wet season, degree of stomach fullness of Pseudotolithus typus samples during the dry season and degree of Stomach fullness of Pseudotolithus typus samples during wet and dry season.

Table 1 shows the gut repletion indices of Pseudotolithus typus samples from Lagos Lagoon during the wet and dry season. The gut repletion index was lower during the wet season with a mean value of 71.11 and higher during the dry season with a mean of 79.26.The maximum gut repletion index of 80.00 was obtained during the wet and dry season while the minimum of 60.00 was obtained during the wet season.

Table 2 shows the gut repletion index Pseudotolithus typus samples for the combined sampling period of six month and has a maximum value of 80.00 with the minimum of 60.00 . The gut repletion index of Pseudotolithus typus samples from Lagos lagoon has a mean of 75.18 for both season. Figure 4 shows the gut repletion index of Pseudotolithus typus samples

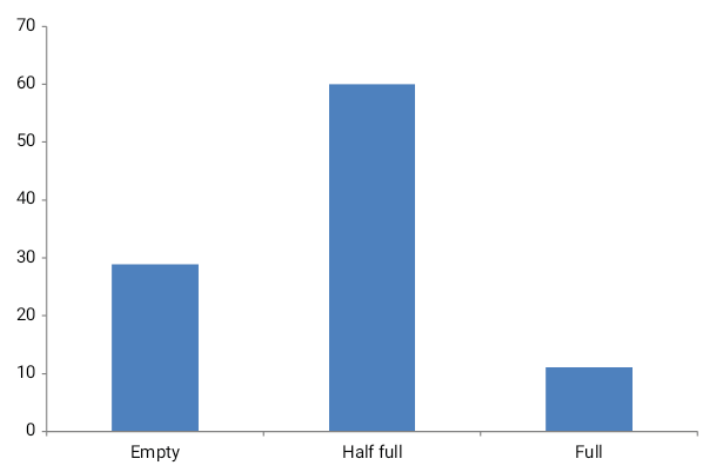

Figure 1: Degree of stomach fullness of Pseudotolithus typus samples during the wet season.

Scale: 1unit represent 10units of stomach found to be Empty, Half full and full

while the $Y$-axis represents the stomach fullness degree are represented on the $x$-axis during the wet season.

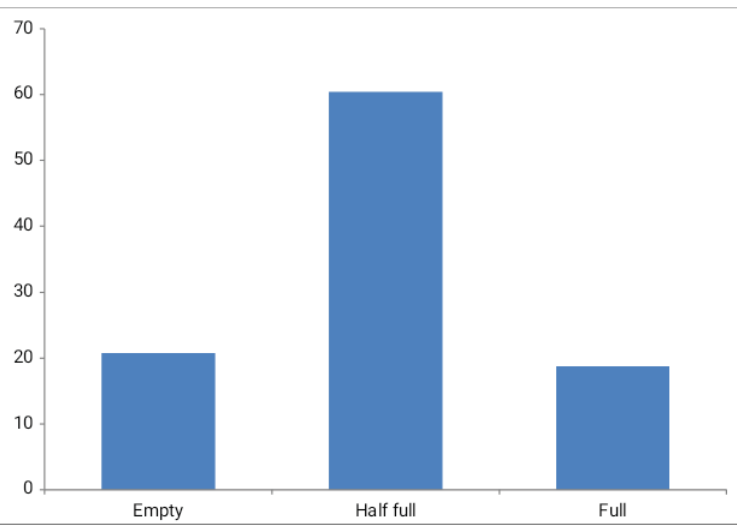

Figure 2: Degree of stomach fullness of Pseudotolithus typus samples during the dry season.

Scale: 1 unit represent 10units of stomach found to be Empty, Half full and full while the $Y$-axis represents the stomach fullness degree are represented on the $\mathrm{x}$-axis during the dry season.

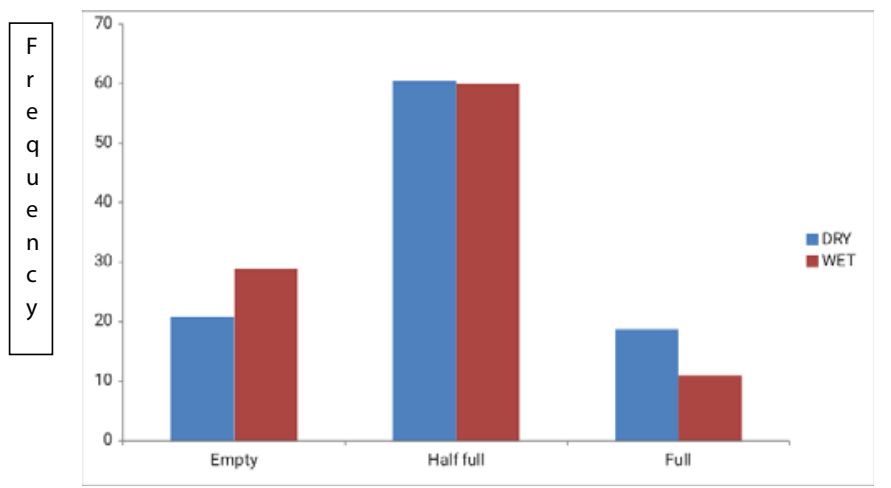

Figure 3: Degree of Stomach fullness of Pseudotolithus typus samples during wet and dry.

Scale: 1unit represent 10percent of frequency of occurrence and Numerical

Dietary Composition of Pseudotolithus typus on Y-axis while the stomach fullness degree are represented on the $x$-axis.

Table 1: Gut repletion index of Pseudotolithus typus in Makoko, Lagos Lagoon for individual season.

\begin{tabular}{|c|c|c|c|}
\hline Season & \multicolumn{3}{|c|}{ Gut repletion index } \\
\hline & Mean \pm SD & Min. & Max. \\
\hline WET & $71.11 \pm 10.18$ & 60.00 & 80.00 \\
\hline DRY & $79.26 \pm 1.29$ & 77.77 & 80.00 \\
\hline
\end{tabular}

Table 2: Gut repletion index of Pseudotolithus typus in Makoko, Lagos lagoon for combined season.

\begin{tabular}{|r|r|r|r|}
\hline Season & \multicolumn{3}{|c|}{ Gut repletion index } \\
\hline & Mean \pm SD & Min. & Max. \\
\hline Both & $75.18 \pm 7.88$ & 60.00 & 80.00 \\
\hline
\end{tabular}

for each month samples from Lagos lagoon (September, 2018 - February, 2019) respectively.

\section{Diet composition}

The diet of Pseudotolithus typus samples from Lagos lagoon consisted mainly of crustaceans (shrimps) and Pisces (fishes). Other food items were unidentified partially digested fish, Unidientified partially digested Crabs, Cephalopods 
and Bivalves. Crustaceans constituted the most important prey group in samples and have a frequency of occurrence of $55.71 \%$. Parapenaeopsis longirostrics had $5.71 \%$ while Paeneus notialis has the highest frequency of occurrence of $48.57 \%$. Figure 4 shows the frequency of occurrence dietary composition of Pseudotolithus typus samples from Lagos lagoon, Nigeria (September, 2018 - February, 2019), while Figure 5 shows the numerical dietary composition of Pseudolithus typus samples within the specified sampling period. Figure 6, shows comparison between the frequency of occurrence and numerical dietary composition of Pseudotolithus typus in Makoko Lagos lagoon, Nigeria (September-February) respectively.

Figure 7 Comparison between Frequency of Occurrence and Numerical dietary Composition of Pseudotolithus typus samples from Lagos lagoon, Nigeria during wet season while.

\section{Discussion}

\section{Gut repletion index of Pseudotolithus typus}

Gut repletion index mean of $75.18 \%$ with minimum of $60 \%$ and maximum of $80 \%$ was observed during the combined

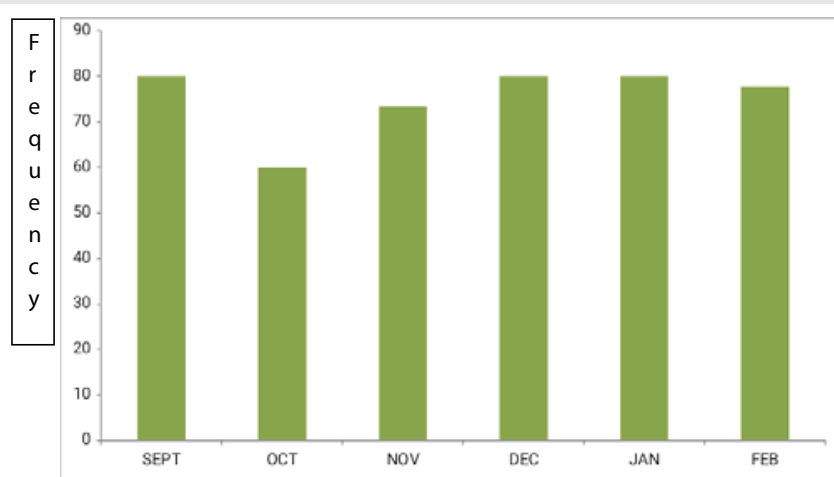

Figure 4: Monthly Gut repletion index of Pseudotolithus typus samples from Lagos lagoon (September, 2018 - February, 2019) for both dry and wet season.

Scale: 1unit represent 10percent of frequency of occurrence and Numerical

Dietary Composition of Pseudotolithus typus on Y-axis while the sampling months are represented on the $\mathrm{x}$-axis

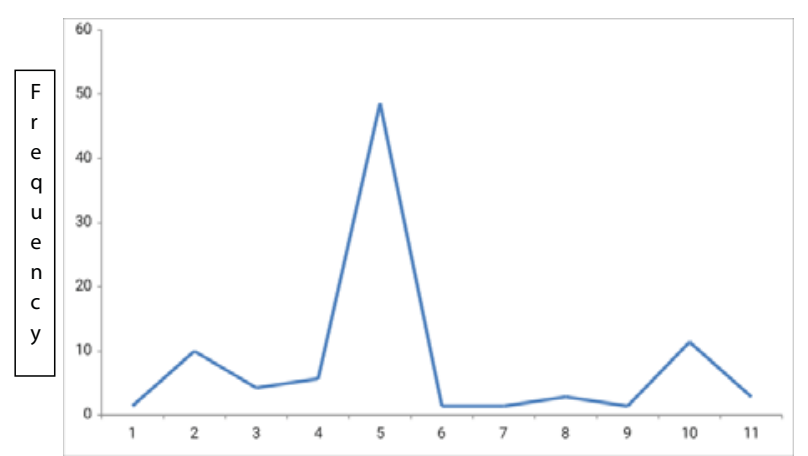

Figure 5: Frequency of Occurrence Dietary Composition of Pseudotolithus typus samples from Lagos lagoon, Nigeria (September, 2018 - February, 2019).

Scale: Each number represents the dietary composition on the $x$-axis:1=Sphyraena barracuda (juvenile), $2=$ Unidientified partially digested fish, $3=$ Unidentified partially digested Cephalopods, 4=Parapenaeopsis longirostrics, 5= Paeneus notialis, $6=$ Unidentified partially digested whole shrimp, $7=$ Unidentified bivalve, $8=$ Callinctes Amnicola, $9=$ Unidentified Crab larva, $10=$ Undigested food item 11=Polychaete 1 unit represent 10percent of frequency of occurrence and Numerical Dietary Composition of Pseudotolithus typus on Y-axis.

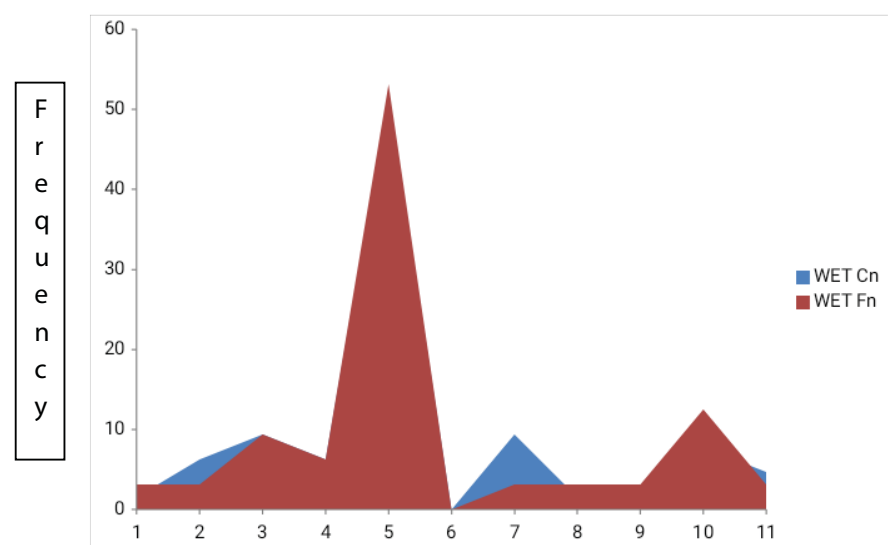

Figure 6: Comparison between Frequency of Occurrence and Numerical dietary Composition of Pseudotolithus typus samples from Lagos lagoon, Nigeria during wet season.

Scale: Each number represents the dietary composition on the $\mathrm{x}$-axis:1=Sphyraena barracuda (juvenile), 2=Unidientified partially digested fish, 3=Unidentified partially digested Cephalopods, 4=Parapenaeopsis longirostrics, 5= Paeneus notialis, $6=$ Unidentified partially digested whole shrimp, $7=$ Unidentified bivalve, $8=$ Callinctes Amnicola, 9=Unidentified Crab larva, 10= Undigested food item 11=Polychaete

1 unit represent 10percent of frequency of occurrence and Numerical Dietary Composition of Pseudotolithus typus on Y-axis.

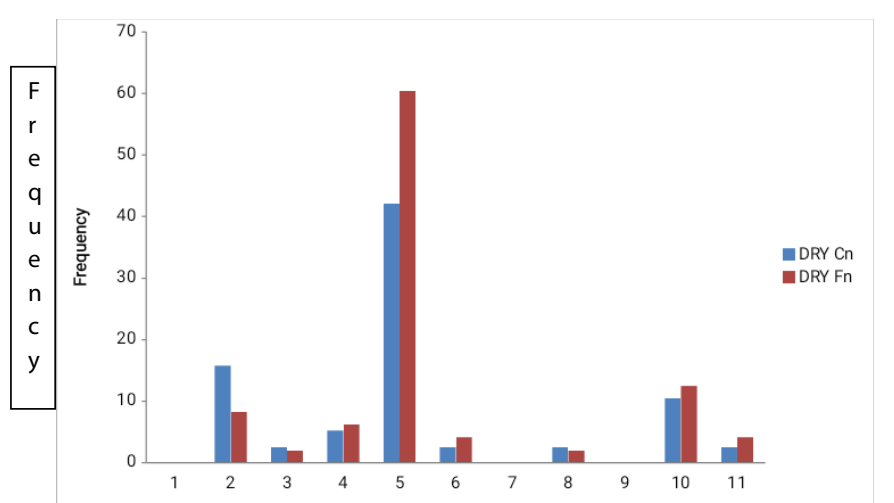

Figure 7: Comparison between Frequency of Occurrence and Numerical dietary Composition of Pseudotolithus typus samples from Lagos lagoon, Nigeria during dry season.

Scale: Each number represents the dietary composition on the $x$-axis: $1=$ Sphyraena barracuda (juvenile), $2=$ Unidientified partially digested fish, $3=$ Unidentified partially digested Cephalopods, 4=Parapenaeopsis longirostrics, 5= Paeneus notialis, 6=Unidentified partially digested whole shrimp, 7=Unidentified bivalve, $8=$ Callinctes Amnicola, $9=$ Unidentified Crab larva, 10= Undigested food item 11=Polychaete.

1 unit represent 10percent of frequency of occurrence and Numerical Dietary Composition of Pseudotolithus typus on Y-axis

sampling period. The observed mean gut repletion index for wet $(71.11 \%)$ and dry $(79.26 \%)$ season is an indication of high feeding intensity. The present information is not in agreement with reports of [13] who observed the $100 \%$ GRI in C. Auratus in Cross river estuary of Nigeria. The high \% GRI exhibited by P.typus might be due to their ability to switch diets due to high abundance of food items.

Fish are capable of changing their gut morphology in response to available food resources and demonstrate high degree of plasticity. However, contrary to the report of high gut

Citation: OM Awotunde (2021) Stomach and gut content of Long Neck Croacker-Pseudotolithus typus (Bleeker,1863) from Lagos Lagoon, Nigera. Ann Mar Sci 5(1): 001-006. DOI: https://dx.doi.org/10.17352/ams.000024 
repletion index in this study [14], reported a low GRI in T. teraia $(4.35 \%)$, E. aeneus $(20.00 \%)$.Based on their feeding intensity observed in this study, Pseudotolithus typus from Lagos lagoon, Nigeria were considered active feeders.

\section{Dietary composition of Pseudotolithus typus}

The diet composition of Pseudotolithus typus shows to be a specialized feeders depending on same food sources with streamlined number of food items. The major food materials reported by the current study were shrimps (Crustaceans). These results confirmed those of [15] who observed and reported that four stomachs out of five contained shrimps [16]. also reported the importance of shrimps in the food regime of $P$. Typus [17]. obtained the similar results while studying the community of Sciaenidae off the Guinean coasts [18]. noted that $P$. typus feeds mostly $(80 \%)$ on shrimps.Similar results have been reported in previous studies in Nigeria [19].

The present study revealed that Paeneus notialis was the most important shrimps species fed on by P. typus in Lagoon during the sampling period [18]. reported similar results for these two Sciaenid fish species off Cameroon. This importance of shrimps in diet composition may be due to their abundance [20] and nutritional benefits. The observed high diet specialization can be attributed to the fact that the dietary sources are largely autochthonous. This could however lead to intra and inter-competition. However, the presence in P. typus attests to the inherent ability of the specie to expand their food items, options should there be any dramatic negative alteration in the availability of the favoured food item.

\section{Seasonal variation in Dietary Composition of Pseudotoli- thus typus from Lagos lagoon, Nigeria}

In this study, it was observed that there was a variation in diets fed on by P.typus during the wet and dry season. There was an obvious absence of Sphyraena barracuda and Bivalves during the dry season while they are present during the wet season. Bivalve molluscs are largely used as bioindicators to monitor the health of aquatic environments in both fresh water and the marine environments [21]. reported that a definite pattern of seasonal variations in pollution could not be established for Lagos lagoon.The presence of bivalves during in the dry season indicates there is a certain level of pollution in Lagos lagoon which contradicts the report by [12]. Bivalves population status or structure, physiology, behavior or the level of contamination with elements or compounds can indicate the state of contamination status of the ecosystem. They are particularly useful since they are sessile so that they are representative of the environment where they are sampled or placed according to U.S. Mussel Watch Programme [22].

\section{Conclusion and recommendation}

The stomach and gut content of Pseudotolithus typus from Lagos lagoon show a great autochthonous pattern and have been grouped into predatory or carnivores feeder. An overlap does not exist in the diet which increases competition among the fish and ensures a narrow spectrum of dietaries. From the study, it can be concluded that Pseudotolithus typus in Lagos lagoon utilize more than one source of food.

My recommendation is that the research should be intensified in other area of pseudotolithus typus nutrition and microbial gut content in other to be able to determine the nutritional technicality of rearing the fish in a cultured environment. Also the pollution level of Lagos lagoon should be determined especially during the dry season(when the water level is low) to be able to determine the remediation methods to use in controlling such.

\section{References}

1. Abdel-Aziz NE, Gharib SM (2007) Food and feeding habits of round Sardinella (Sardinella aurita) in El-Mex Bay, Alexandria. Egyptian Journal for Aquaculture 33: 202-221. Link: https://bit.ly/31BUsSF

2. Bachok Z, Mansor MI, Noordin RM (2004) Diet composition and food habits of demersal and pelagic marine fishes from Terengganu waters, east coast of Peninsular, Malaysia. NAGA WorldFish Center Quarterly 27: 41-43. Link: https://bit.ly/3rEdMJB

3. Akpan AW, Isangedighi IA (2004) Aspects of the feeding ecology of three species of Pseudotolithus (Sciaenidae) in the inshore waters of Southeastern Nigeria, East of the Niger Delta, Nigeria. Journal Aquatic Science 19: 51-58. Link: https://bit.ly/31vkW8m

4. Isangedighi IA (2014) Trophic ecology of Pseudotolithus elongatus (Sciaenidae: Teleostei) in the Cross River Estuary, Nigeria. World Journal of Applied Science and Technology 6: 20-25. Link: https://bit.ly/3wgNwbs

5. Isangedighi IA, Ambrose EE (2015) Aspects of the Reproductive strategy of Pseudotolithus elongates (Teleostei: Sciaenidae) in the Cross River estuary, Nigeria. International Journal of Multidisciplinary Research and Development 2: 593-595. Link: https://bit.ly/3m5aHRD

6. Nunoo FKE, Sossoukpe E, Adite A, Fiog-be ED (2013) Food habits of two species of Pseudotolithus (Sciaenidae) off Benin (West Africa) nearshore waters and implications for management International. Journal of Fisheries and Aquaculture 5: 142-151.

7. Benard (2015) Biometric Characteristics, Food and Feeding Habit and Sex Dimorphism of the Long Neck Croaker (Pseudotolithus typus) from Lagos Lagoon. International Journal of Modern Plant Animal Sciences 4: 1-9

8. Udoma O (2013) Makoko: Venice of lagos. world bank public participation policies and processes in relation to the lives of beneficiaries in slum upgrading projects: case study: Makoko, Lagos, Nigeria.

9. Schneider W (1990) Field guide to the commercial marine resources of the Gulf of Guinea. FAO, Rome 227. Link: https://bit.ly/2QleHvB

10. Hyslop EJ (1980) Stomach content analysis: a review of methods and their application. Journal of Fish Biology 17: 411-429. Link: https://bit.ly/3m8sQ0E

11. Frost WE (1946) On the food relationships of the fish in Windermere. Biol Jaavb 13

12. Smyly WJP (1952) Observations on the food of fry of perch (Pwca,fluviatili.s Linn.) in Windermere. Proceeding of the zoological society of London 122 : 407-416

13. Offem BO, Samsons YA, Omoniyi IT (2009) Length-weight Relationship Condition Factor and Sex Ratio of Forty Six Important Fishes in a Tropical Flood River. Research Journal of Fisheries and Hydrobiology 4: 65-72. Link: https://bit.ly/3rAkGiL

14. Ekpo IE, Essien-lbok MA, Nkwoji JN (2014) Food and feeding habits and condition factor of fish species in Qua Iboe River estuary, Akwa Ibom State, 
southeastern Nigeria. International Journal of Fisheries and Aquatic Studies 2: 38-46. Link: https://bit.ly/31yhsSv

15. Troadec JP (1971) Biologie et dynamique d'un Sciaenidae ouest-africain Pseudotolithus senegalensis (V.). Doc. Scient. Centre Rech. Océanogr, Abidjan 2: 1-225. Link: https://bit.ly/39raDqk

16. Baran E (1995) Dynamique spatio-temporelle des peuplements depoisons estuariens en Guinée - relation avec le milieu abiotique.Thèse de Doctorat, Université de Bretagne Occidentale, Brest. France 242. Link: https://bit.ly/3m6ZLCR

17. Sidibé A (2003) Les ressources halieutiques démersales côtières de la Guinée. Exploitation, biologie et dynamique des principales espèces de la communauté à Sciaenidae. Thèse Doct., Ensar. Rennes France 320. Link: https://bit.ly/31BySxs
18. Tientcheu JY, Djama T (1994) Food habits of two Sciaenid fish species (Pseudotolithus senegalensis and Pseudotolithus typus) of Cameroon. Fishbyte section, Nanga. The International center for living Aquatic Resources Management Quaterly 40. Link: https://bit.ly/3djqY1e

19. Longhurst AR (1964) Synopsis of biological data on West African croakers (P.typus,P.senegalensis and P. elongatus). FAO Fish. Synopsis 35. Link: https://bit.ly/3u6dPPW

20. Lagler KF, Bardack JE, Miller RR, Passino DRM (1977) Ichthyology. John Wiley Inc., New York. USA 506

21. Ajani EK, Omitoyin BO, Abass A (2003) The physico-chemical parameters and pollution status of Lagos Lagoon in Lagos Lagoon, Nigeria. Journal of tropical Forest 19: 145-160.

22. Center for Coastal Monitoring and Assessment (2014) Mussel Watch Contaminant Monitoring. Ccma.nos.noaa.gov.

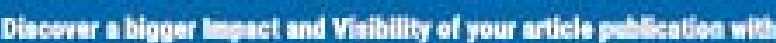
Peertechz Publications

\section{Highlights}

- Spualsy putaner af OMoD

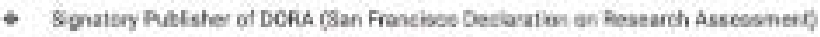

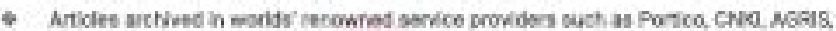

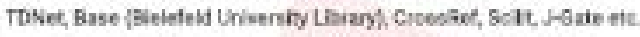

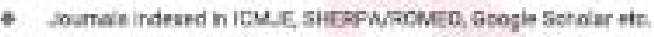

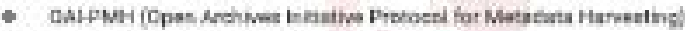

* Deticated Eshoris Baerd for nery journa

- Acturate and rapid peecreview prosts:

- hereasad etobions of putishad artides through promotisns

6. Reduned tmelhe sor artale pilingtion

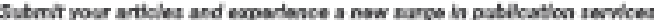

(Mitps:Srww peertachz ecro/nubmissbon)

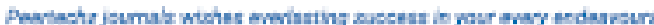

Copyright: @ 2021 OM Awotunde. This is an open-access article distributed under the terms of the Creative Commons Attribution License, which permits unrestricted use distribution, and reproduction in any medium, provided the original author and source are credited.

Citation: OM Awotunde (2021) Stomach and gut content of Long Neck Croacker-Pseudotolithus typus (Bleeker,1863) from Lagos Lagoon, Nigera. Ann Mar Sci 5(1): 001-006. DOI: https://dx.doi.org/10.17352/ams.000024 